\title{
THE EFFECT OF GENDER IN THE BOARD OF COMMISSIONERS ON COMPANY VALUE WITH FAMILY CONTROL AS A MODERATION VARIABLE IN INDONESIA
}

\author{
Elsa Limbago, Dedhy Sulistiawan \\ Universitas Surabaya, Surabaya, Indonesia
}

\begin{abstract}
Gender has been a concern because gender differences affect the effectiveness of running a company and making decisions, so that, it can affect the company's value. Indonesia is a country with the majority ownership of companies owned by families which will have an impact on the composition in the election of company boards. The results of previous studies regarding the effect of gender on companies are remains inconsistent. This study aims to determine the effect of gender in the board of commissioners on company value and the influence of family control in weakening the effect of gender in the board of commissioners on the company's value. This research was measured firm value by using Tobin's $\mathrm{Q}, \mathrm{PBV}$, and PER. The control variables used were firm size, commissioner size, and leverage. This research used all companies listed on the IDX as samples, except the financial and banking sectors, and is analyzed using multiple linear regression. The results proved that gender in the board of commissioners has no significant effect on the company's value, and there is no significant influence on family control in weakening the effect of gender in the board of commissioners on company value.
\end{abstract}

Keywords: gender, family control, Tobin's Q, PBV, PER

\section{Introduction}

The main challenge faced by companies is to align the different interests between management and stakeholders. This is called the agency theory (Donaldson and Davis, 1991). Stakeholders want large profits, to achieve higher returns (Abdullah and Valentine, 2009). On the other hand, management prioritizes its

\footnotetext{
*Corresponding Author.

e-mail: elsa_limbago@yahoo.com
} 
own interests to achieve high salaries, bonuses, and achievements, among others, to make a better career (Davis et al., 1997). To align the interests of management and shareholders, good governance is needed (Donaldson and Davis, 1991). The company's governance is divided into two systems. One Tier is a system where there is a single board consisting of executives and non-executives. This system is adopted by countries such as the United Kingdom and Ireland (Jungmann, 2006). Whereas in the two tiers system, there is a separation between the management board and the supervisory board. This is adopted in countries such as the Netherlands, China, and Germany (Aguilera, 2005). Board of directors play a key role in management monitoring and in establishing mechanisms that align management and stakeholder objectives (Erhardt et al., 2003). Boards of directors in a one tier system is different from one using a two tier system. Indonesia adopts the two-tier system so that the board of directors is analogous to the role of the board of commissioners whose task is to monitor management performance (Wardhani, 2008).

Membership differences in the board of commissioners can provide an overview of the effectiveness in carrying out responsibilities and thus can influence actions and decisions that impacts company performance and value (Carter et al., 2010). Membership differences in the board of commissioners can be in the form of gender, ethnicity, and culture (Carter et al., 2003). The higher the level of diversity in the board of commissioners, the higher the propensity for conflict, but the conflict will lead to positive outcomes. This is because diversity in groups will lead to differences in problem assessment and resolution in which emerging ideas tend to lead towards innovation and creativity, which can be a advantage for the company (Kiran, 2014; Chapple and Humphrey, 2014). Conversely, a homogeneous composition of the board will lead to a narrower perspective (Kusumastuti et al., 2008).

The majority of company ownership in Indonesia is owned by families (Darmadi, 2013). In family businesses, the family tends to appoint family members as board members because they are considered to be more trustworthy (Jaggi et al., 2009). This will affect the level of diversity in the board because the selection of board members does not consider factors of diversity such as gender, experience, and expertise but rather the relationship with the founder or the controlling shareholder (Darmadi, 2013). Conversely, a board of commissioners 
with increasingly diverse members can add value by presenting new ideas in the decision-making process. On the other hand, when there is gender diversity in the board of commissioners, the board of commissioners tends to work in more detail and diligently so that the monitoring process becomes more robust (Adams and Ferreira, 2009; Yap Lee-Kuen et al., 2017). However, a more robust monitoring can cause disruptions in communication between managers and the board of directors due to excessive interference (Adams and Ferreira, 2007). This makes managers reluctant to provide information to the board of directors and adversely affects the performance and value of the company. Gender diversity in the council also causes increased potential for conflict and thus it becomes more difficult to reach agreement in meetings (Jehn et al., 1999; Lau and Murnighan, 1998). This can influence the value of the company.

The inconsistency of the results of research in various countries is the driving factor of this research, especially because there is no research on this topic using moderating variables. Researches by (Adams and Ferreira, 2009; Ruuska, 2017; Carter et al., 2003; Yap Lee-Kuen et al., 2017; Erhardt et al., 2003; Nguyen and Faff, 2007; Shafique et al., 2014; Dewi and Dewi, 2016 ) show the influence of gender in the board of the company's value. Yap Lee-Kuen et al. (2017) conducted a research on companies in Malaysia and proved the influence of gender in the board on the value of the company. This is because gender diversity increases company innovation and creativity in decision making. Women are also found to have more perseverance in the monitoring process and demand greater accountability for management performance. Diversity on the board increases income quality through reducing opportunistic behavior in earnings management because women are less tolerant to opportunistic behavior. On the other hand, researches by (Asri, 2017; Gallego et al., 2010; Darmadi, 2013) proved that there is no significant influence of gender in the board on firm value. Darmadi (2013) conducted a study in Indonesia and showed that there is no significant influence of gender on the board on company value. This is because the majority of companies registered in Indonesia are owned by families so that the election of board members is based on family ties with controlling shareholders and not based on expertise or professional experience. As a result, the lack of competence will affect the performance and value of the company. Darmadi (2013) conducted a study in Indonesia and showed that there is no 
significant influence from gender in the board on company value. This is because the majority of companies registered in Indonesia are owned by families so that the election of board members is based on family ties with controlling shareholders and not because of expertise or professional experience.

Based on the studies above, the authors are interested in conducting research into the influence of gender in the board of commissioners on the value of the company and the role of family control to the influence of gender in the board of commissioners on the value of the company in all companies listed on the Stock Exchange except in the financial sector for the period of 2015-2017.

\subsection{The Effect of Gender on the Board of Commissioners on Company Value}

Managing diversity in the composition of the board of commissioners is important because it relates to the characteristics, quality, and expertise of members that can influence the actions and decisions of the company board (Ruigrok et al., 2007; Lückerath-Rovers, 2013; Carter et al., 2010). One type of diversity is gender composition. Genders on an increasingly diverse board of commissioners will make a difference in looking at problems and finding solutions so that new ideas emerge may better lead to innovation and creativity, which can be advantageous to the company (Kiran, 2014; Chapple and Humphrey, 2014). Boards of commissioners with an increasingly high level of gender diversity will also work better in terms of monitoring and demanding greater accountability for management performance. This will improve income quality through reducing opportunistic behavior in earnings management because women are less tolerant of opportunistic behavior. This lack of tolerance is due to how women judge the appropriateness of actions independently and how they have a higher level of moral maturity (Srinidhi et al., 2011). Women also think more about social reputation in making decisions (Asri, 2007). In the research conducted by Lückerath-Rovers (2013), diversity in the board of commissioners will provide benefits because it better reflects the demographic characteristics of key stakeholder groups such as customers, employees, and investors. Therefore, the decisions made are taken through consideration with a broader perspective. The diversity of the board of commissioners will also be useful in improving the company's reputation for employees because both men and women are given 
equal opportunities in their careers. Increasing company excellence and reputation will increase market confidence, and thus will increase the company's value (Kusumastuti et al., 2008). Based on the explanation above, the hypothesis taken is

$\mathrm{H} 1=$ Gender in the Board of Commissioners influences company value.

\subsection{The role of family control over the effect of gender in the Board of Commissioners on Company Value}

In active family companies, the family will become a board member (Siregar, 2008). The family will also try to minimize the presence of an independent board of commissioners by appointing board members who have ties to the family because they are considered more trustworthy (Jaggi et al., 2009; Darmadi, 2013; Anderson and Reeb, 2004). The family company will be controlled by people who have a relationship with the founder or majority shareholder (Darmadi, 2013). Corporate opportunities to obtain board members with the required qualifications are limited, including regarding gender diversity, expertise, and education on the board of commissioners (Mishra and McConaughy, 1999; Campbell and Mínguez-Vera, 2008; Muttakin et al., 2015). Significant control by the company founder coupled with the board of commissioners related to the family will cause the monitoring process to be ineffective and increase the possibility of opportunistic behavior carried out by the family (McConaughy and Phillips, 1999; Anderson and Reeb, 2004). Opportunities for exploitation of minority shareholders become greater. This will have a negative impact on investors' assessment of the company (Anderson et al., 2003). Based on the explanation above, the hypothesis taken is

$\mathrm{H} 2$ = Family control will weaken the influence of gender in the board of commissioners on the company's value

\section{Research Methodology}

This research uses multiple regression analysis. The relationship between the variables studied is stated with the analysis model as follows: 


\begin{tabular}{lrrr}
\hline Variable & B & Sig. t & Sig. F \\
\hline Constant & 1,290 & 0,000 & 0,095 \\
GDK & $-0,239$ & 0,095 & \\
\hline
\end{tabular}

The population used is all publicly listed companies on the Indonesia Stock Exchange in 2015-2017, except companies in the financial and banking sectors. The sample used is companies that meet certain criteria (purposive sampling). The criteria in question are public companies on the Indonesia Stock Exchange from at least 2014 and those which have a complete annual report for the 20152017 period. The number of samples that met the criteria is 1,242 companies and the number remaining sample after the process of removing outlier data is 1,077 .

The analysis model used in this study:

$\mathrm{TQ} / \mathrm{PBV} / \mathrm{PER}=\alpha 0+\alpha 1 \mathrm{GDK}+\alpha 2 \mathrm{FC}+\alpha 3(\mathrm{GDK} * \mathrm{FC})+\alpha 4 \mathrm{SIZE}+\alpha 5 \mathrm{CS}+$ $\alpha 6 \mathrm{LVR}+\varepsilon \ldots$

whereas:

- TQ/PBV/PER is company value

- $\alpha 0$ is constant value

- $\alpha 1-\alpha 6$ are the coefficient of each variable

- GDK is the gender in the board of commissioners

- FC is family control

- SIZE is company size

- $\mathrm{CS}$ is commissioner size

- LVR is leverage

- $\varepsilon$ is the error prediction

\section{Results and Discussion}

\subsection{Results}

The following are the variables after the classical assumption test: 
Elsa Limbago, Dedhy Sulistiawan / The Effect of Gender in the Board of Commissioners on Company Value with Family Control as a Moderation Variable in Indonesia

Table 1 Descriptive Statistics

\begin{tabular}{lrrrrr}
\hline & N & Minimum & Maximum & Mean & $\begin{array}{c}\text { Std. } \\
\text { Deviation }\end{array}$ \\
\hline GDK & 1077 &, 00 &, 75 &, 1123 &, 17115 \\
FC & 1077 &, 00 & 1,00 &, 6955 &, 46043 \\
GDKXFC & 1077 &, 00 &, 75 &, 0776 &, 15110 \\
SIZE & 1077 & 10,18 & 14,47 & 12,4511 &, 71765 \\
CS & 1077 &, 00 & 22,00 & 4,2043 & 1,86213 \\
LVR & 1077 & $-6,69$ & 59,56 &, 5752 & 1,86213 \\
TQ & 1077 &, 12 & 5,40 & 1,2628 &, 80429 \\
PBV & 1077 & $-2,85$ & 64,43 & 1,4681 & 2,46330 \\
PER & 1077 & $-572,18$ & 548,56 & 14,2533 & 62,97858 \\
\hline
\end{tabular}

Table 2 Frequency Statistics

\begin{tabular}{lcc}
\hline & Frequency & Percent \\
\hline Non family control & 328 & 30,5 \\
Family control & 749 & 69,5 \\
Total & 1077 & 100 \\
\hline
\end{tabular}

Table 3 Results of Linear Regression Test Model 1

\begin{tabular}{lccc}
\hline \multicolumn{1}{c}{ Variable } & B & Sig. $\mathbf{~}$ & Sig. $\mathbf{F}$ \\
\hline Constant & 1,442 & 0,002 & 0,000 \\
& & & \\
GDK & 0,135 & 0,596 & \\
FC & 0,088 & 0,159 & \\
GDKXFC & $-0,474$ & 0,121 & \\
SIZE & $-0,046$ & 0,238 & \\
CS & 0,085 & 0,000 & \\
LVR & $-0,007$ & 0,493 & \\
\hline
\end{tabular}

Table 4 Results of Linear Regression Test Model 2

Simple Regression Model 2

\begin{tabular}{lccc}
\hline \multicolumn{1}{c}{ Variable } & B & Sig. $\mathbf{~}$ & Sig. $\mathbf{F}$ \\
\hline Constant & 1,441 & 0,000 & 0,587 \\
GDK & 0,238 & 0,587 & \\
\hline
\end{tabular}


Double Linear Regression Model 2

\begin{tabular}{lccl}
\hline \multicolumn{1}{c}{ Variable } & B & Sig. $\mathbf{~}$ & Sig. F \\
\hline Constant & 2,388 & 0,018 & 0,000 \\
GDK & 0,674 & 0,225 & \\
FC & 0,204 & 0,137 & \\
GDKXFC & $-0,822$ & 0,218 & \\
SIZE & $-0,176$ & 0,039 & \\
CS & 0,163 & 0,000 & \\
LVR & 0,747 & 0,000 & \\
\hline
\end{tabular}

Table 5 Results of Linear Regression Test Model 3

Simple Regression Model 3

\begin{tabular}{lccc}
\hline \multicolumn{1}{c}{ Variable } & B & Sig. $\mathbf{~ t}$ & Sig. F \\
\hline Constant & 12,637 & 0,000 & 0,199 \\
GDK & 14,400 & 0,199 & \\
\hline
\end{tabular}

Double Linear Regression Model 3

\begin{tabular}{llll}
\hline \multicolumn{1}{c}{ Variable } & \multicolumn{1}{c}{ B } & Sig. t & Sig. F \\
\hline Constant & $-54,200$ & 0,138 & 0,099 \\
GDK & $-14,152$ & 0,483 & \\
FC & $-4,664$ & 0,350 & \\
GDKXFC & 44,089 & 0,069 & \\
SIZE & 5,443 & 0,078 & \\
CS & 0,502 & 0,672 & \\
LVR & $-0,030$ & 0,971 & \\
\hline
\end{tabular}

\subsection{Discussion}

\subsubsection{Gender in the Board of Commissioners influences company value}

The results of t-test proved that there is no significant influence of gender on the board of commissioners with the value of the company which is proxied by Tobins Q (Regression 1), PBV (Regression 2), and PER (Regression 3). The value of the gender variable in the board of commissioners has a positive or negative effect, but it is not significant, meaning that both women and men who are in the board of commissioners tend to not affect the value of the company. Thus, hypothesis 1 was rejected because gender in the board of commissioners 
do not significantly influence Tobin's Q, PBV, and PER. The results of this study indicate that the company's value is not determined by the gender in the board of commissioners. For the agency theory, the results in this study indicate that gender diversity in the board of commissioners does not increase investor confidence because there is no significant effect of gender diversity in the board of directors found on the company's value. The results of this study are in line with a previous research conducted by Gallego et al. (2010) which proved that gender in the board of commissioners does not significantly influence the value of the company because investors do not only pay attention to gender in the board of commissioners but also pay more attention to other aspects such as background, education, training, and experience. Kiran (2014) and Erhardt et al. (2003) explained that experience and competence were given more attention in the composition of the board of commissioners because it can build good communication and will then improve company performance and value.

\subsubsection{Family control will weaken the influence of gender in the board of commissioners on the company's value}

Based on the results of the t-test, there is no significant influence that family control weakens the influence of gender in the board of commissioners on the value of the company proxied by Tobins Q (Regression 1), PBV (Regression 2), and PER (Regression 3). The value of the family control variable will weaken the influence of gender in the board of commissioners on the insignificant value of the company, meaning that companies owned by the family tend not to weaken the influence of gender in the board of commissioners on the company's value. Thus, hypothesis 2 is rejected because family control weakens the influence of gender in the board of commissioners and does not significantly influence Tobin's Q, PBV, and PER. From the results of this study, it turns out the value of the company is not determined by the influence of family control on gender in the board of commissioners. Controlling shareholders will tend to ensure that there is no expropriation of minority shareholders because the existence of expropriation will cause outside investors to value the company's shares low, which will then be reluctant to invest and will affect the value of the company (Claessens et al., 2000; Jensen and Meckling, 1976; Siregar, 2008). This 
insignificant result also occurred because in Indonesia there were only a few women who successfully served in a board of commissioners. Based on data on companies in Indonesia except in the financial and banking sectors, there are $63 \%$ of companies that do not have a female member in their board of commissioners.

\section{Conclusions, Limitations, and Suggestions}

\subsection{Conclusions}

The conclusions of this research are:

1. There is no significant influence between gender in the board of commissioners on the value of the company.

2. There is no significant influence of family control in weakening the influence of gender in the board of commissioners on company value. However, the regression results on profit companies and large companies show that when a company is a family-controlled company and has a woman as a member of the board of commissioners because of family relations with the majority shareholders, then there is a significant negative effect on the value of the company which is measured using PBV.

\subsection{Limitations}

The limitations of this research are:

1. This study has a limited grouping of samples because it is limited to all sectors except the financial sector listed on the Indonesia Stock Exchange for the period 2015-2017.

2. The measurement of family control in this study is only limited to seeing one layer of ownership and seeing the activeness of family ownership in the company.

3. Gender measurement in this study is only limited to gender in the board of commissioners.

4. Gender measurements in this study are based only on female and male gender.

5. This research was only conducted on companies in Indonesia. 


\subsection{Suggestions}

Suggestions for future researches from the researcher are:

1. Research should be carried out using more samples, and not limited to three years.

2. Family control variables should be measured to ultimate ownership because tracing is carried out until a controlling shareholder is found.

3. The next research should use gender in the board of directors because the board of directors is involved in the company's operations while the board of commissioners only monitors the performance of management so that it tend to not be directly influencing the company.

4. The next research should look at the gender in the perspective of femininity and masculinity because in the perspective of the intrapsychic theory, femininity and masculinity influence leadership styles and behaviors regardless of gender differences.

5. The next research should use a wider sample and not only in Indonesia as well as examine the diversity of members in regards of not only gender but also the experience, professionalism, and background of the members of the board of commissioners.

\section{Reference}

Abdullah, H. \& Valentine, B. 2009. Fundamental and Ethics Theories of Corporate Governance. Middle Eastern Finance and Economics, 4(4), 8896.

Adams, R.B. \& Ferreira, D. 2009. Women in the Boardroom and Their Impact on Governance and Performance. Journal of Financial Economics, 94(2), 291-309.

Adams, R.B. \& Ferreira, D. 2007. A Theory of Friendly Boards. The Journal of Finance. 62(1), 217-250.

Aguilera, R.V. 2005. Corporate Governance and Director Accountability: An Institutional Comparative Perspective. British Journal of Management, 16, S39-S53. 
Anderson, R.C. \& Reeb, D.M. 2004. Board Composition: Balancing Family Influence in S\&P 500 Firms. Administrative Science Quarterly, 49(2), 209237.

Anderson, R.C., Mansi, S.A., \& Reeb, D.M. 2003. Founding Family Ownership and the Agency Cost of Debt. Journal of Financial Economics, 68(2), 263285.

Asri, M. 2017. The Impact of Female Directors on Firm Performance: Evidence From Indonesia. Journal of Indonesian Economy and Business: JIEB, 32(1), 19-32.

Boubaker, S., Dang, R., \& Nguyen, D.K. 2014. Does Board Gender Diversity Improve the Performance of French Listed Firm? Gestion 2000, 31(1), 259-269.

Campbell, K. \& Mínguez-Vera, A. 2008. Gender Diversity in the Boardroom and Firm Financial Performance. Journal of Business Ethics, 83(3), 435-451.

Carter, D.A., D'Souza, F., Simkins, B.J., \& Simpson, W.G. 2010. The Gender and Ethnic Diversity of US Boards and Board Committees and Firm Financial Performance. Corporate Governance: An International Review, 18(5), 396414.

Carter, D.A., Simkins, B.J., \& Simpson, W.G. 2003. Corporate Governance, Board Diversity, and Firm Value. Financial Review, 38(1), 33-53.

Chapple, L. \& Humphrey, J.E. 2014. Does Board Gender Diversity Have a Financial Impact? Evidence Using Stock Portfolio Performance. Journal of Business Ethics, 122(4), 709-723.

Darmadi, S. 2013. Do Women in Top Management Affect Firm Performance? Evidence from Indonesia. Corporate Governance: The International Journal of Business in Society, 13(3), 288-304.

Darwis, H. 2009. Corporate Governance terhadap Kinerja Perusahaan. Jurnal Keuangan dan Perbankan, 13(3).

Daunfeldt, S.O. \& Rudholm, N. 2012. Does Gender Diversity in the Boardroom Improve Firm Performance. Departamento de Economía de la Universidad de Dalarna, 781(88).

Davis, J.H., Schoorman, F.D., \& Donaldson, L. 1997. Toward a Stewardship Theory of Management. Academy of Management Review, 22(1), 20-47. 
Dewi, G.K. \& Dewi, A.A. 2016. Pengaruh Diversitas Dewan Komisaris dan Direksi pada Nilai Perusahaan pada Perusahaan Sektor Keuangan yang Terdaftar di Bursa Efek Indonesia Tahun 2009-2013. E-Jurnal Akuntansi, 812-836.

Donaldson, L. \& Davis, J.H. 1991. Stewardship Theory or Agency Theory: CEO Governance and Shareholder Returns. Australian Journal of management, 16(1), 49-64.

Erhardt, N.L., Werbel, J.D., \& Shrader, C.B. 2003. Board of Director Diversity and Firm Financial Performance. Corporate Governance: An International Review, 11(2), 102-111.

Gallego-Álvarez, I., García-Sánchez, I. M., \& Rodríguez-Dominguez, L. 2010. The Influence of Gender Diversity on Corporate Performance. Revista de Contabilidad, 13(1), 53-88.

Jaggi, B., Leung, S., \& Gul, F. 2009. Family Control, Board Independence and Earnings Management: Evidence Based on Hong Kong Firms. Journal of Accounting and Public Policy, 28(4), 281-300.

Jehn, K.A., Northcraft, G.B., \& Neale, M.A. 1999. Why Differences Make a Difference: A Field Study of Diversity, Conflict, and Performance in Workgroups. Administrative Science Quarterly, 44(4), 741-763.

Jungmann, C. 2006. The Effectiveness of Corporate Governance in One-Tier and Two-Tier Board Systems-Evidence from the UK and Germany. European Company and Financial Law Review, 3(4), 426-474. 
Review of Management and Entrepreneurship

Volume 03, Number 02, October 2019 